\title{
Data Terbaru Jenis-Jenis Kupu-Kupu di Desa Serdang Menang
}

\author{
Ari Sugiarto \\ Email: sugiartoari13@gmail.com
}

\begin{abstract}
Abstrak
Terdapat 10 spesies kupu-kupu dari 10 genus dan 6 famili di Desa Serdang Menang berdasarkan hasil penelitian pada tahun 2018. Data spesies kupu-kupu yang didapat dinilai terlalu sedikit dibandingkan dengan keberagaman ekosistem hijau yang terdapat di Desa Serdang Menang yang sangat mendukung habitat bagi kupu-kupu. Penelitian lanjutan mengenai jenis-jenis kupu-kupu di Desa Serdang Menang akan sangat membantu dalam melengkapi data penelitian sebelumnya guna mengetahui data jenis-jenis kupu-kupu dan dapat menjadi evaluasi penelitian sebelumnya. Penelitian ini dilukan pada November 2018-Oktober 2019 dengan menggunakan metode jelajah. Hasil Peneltian ditemukan 40 spesies kupu-kupu dari 26 genus dan 5 famili. Spesies kupu-kupu dari famili Nymphalidae mendominasi dengan jumlah spesies 16, Pieridae 8 spesies, Papilionidae 7 spesies, Hesperiidae 6 spesies dan Lycaenidae 3 spesies. Spesies kupu-kupu dari genus Papilio paling banyak dengan 5 spesies, Junonia dengan 4 spesies dan Catopsilia dengan 3 spesies.
\end{abstract}

Kata Kunci: Desa Serdang Menang, Kupu-Kupu

\section{Pendahuluan}

Data jenis-jenis kupu-kupu di Desa Serdang Menang, Kecamatan Sirah Pulau Padang, Kabupaten Ogan Komering Ilir, Sumatera Selatan menunjukkan terdapat 10 spesies kupu-kupu dari 10 genus dan 6 famili. Famili Nymphalidae dan Pieridae mendominasi dengan jumlah masingmasing 3 spesies kupu-kupu, sedangkan famili Hespriidae, Lycaenidae, Papilionidae dan Riodinidae dengan jumlah masing-masing 1 spesies kupu-kupu (Sugiarto, 2018). Data jenis-jenis kupukupu di Desa Serdang Menang dinilai terlalu sedikit, hal ini dipertimbangkan dari kondisi ekosistem di Desa Serdang Menang yang masih terjaga serta memiliki kergaman tipe ekosistem. Menurut Sugiarto (2018), Desa Serdang Menang terdiri dari ekosistem yang masih hijau seperti persawahan, perkebunan dan tepian sungai. Ekosistem yang hijau dapat menyediakan vegetasi yang mendukung habitat kupukupu (Rahayu \& Basukriadi, 2012) dan dapat menyediakan sumber makanan bagi kupu-kupu (Septianella et al., 2015).
Penelitian lanjutan jenis-jenis kupukupu di Desa Serdang Menang akan sangat membantu dalam melengkapi data penelitian sebelumnya guna mengetahui data jenis-jenis kupu-kupu dan dapat menjadi evaluasi penelitian sebelumnya. Oleh karena itu perlu dilakukan penelitian lanjutan mengenai jenis-jenis kupu-kupu di Desa Serdang Menang.

\section{Metode Penelitian}

Penelitian ini dilaksanakan pada November 2018-Oktober 2019 di Desa Serdang Menang, Kecamatan Sirah Pulau Padang, Kabupaten Ogan Komering Ilir, Sumatera Selatan. Metode penelitian lanjutan ini sama dengan metode penelitian yang dilakukan oleh Sugiarto (2018) yang mengikuti metode penelitian Dalem \& Joni (2017) yaitu dengan metode jelajah. Sampel kupu-kupu ditangkap dengan jaring serangga, selain itu juga digunakan kamera ponsel untuk mengambil foto kupu-kupu. Kupu-kupu yang didapat dari jaring serangga dimasukkan kedalam amplop dari kertas minyak agar sample tidak rusak. Pengambilan sampel ini lebih diutamakan 
hanya mengambil foto kupu-kupu dengan menggunakan kamera ponsel untuk menjaga kelestarian kupu-kupu. Sampel kupu-kupu yang dikoleksi hanya ditangkap jika dilihat jumlah spesiesnya cukup banyak.

Identifikasi sampel kupu-kupu juga dilakukan dengan cara yang sama oleh
Sugiarto (2018) yaitu dengan mencocokkan foto sampel dengan foto spesies kupu-kupu yang telah teridentifikasi jenisnya pada website indentifikasi kupu - kupu. Perbedaan penelitian ini dengan penelitian sebelumnya hanya terletak pada lama waktu penelitian.

\section{Hasil dan Pembahan}

Total ditemukan 40 spesies kupu-kupu (Tabel 1) dari 26 genus dan 5 famili. Spesies kupukupu dari famili Nymphalidae mendominasi dengan jumlah spesies 16, Pieridae 8 spesies, Papilionidae 7 spesies, Hesperiidae 6 spesies dan Lycaenidae 3 spesies. Spesies kupu-kupu dari genus Papilio paling banyak dengan 5 spesies, Junonia dengan 4 spesies dan Catopsilia dengan 3 spesies.

Tabel 1. Jenis-jenis kupu-kupu di Desa Serdang Menang

\begin{tabular}{|c|c|c|c|}
\hline Famili & Genus & Spesies & Nama Umum \\
\hline \multirow[t]{5}{*}{ Hesperiidae } & Ampittia & $\begin{array}{l}\text { A. dioscorides } \\
\text { sp. }\end{array}$ & $\begin{array}{l}\text { Common bush hopper } \\
\text { - }\end{array}$ \\
\hline & Hosora & sp. & - \\
\hline & Matapa & M. aria & Common redeye \\
\hline & Potantus & $P$. serina & Large dart \\
\hline & Telicota & sp. & - \\
\hline \multirow[t]{3}{*}{ Lycaenidae } & Cheritra & C. freja & Common imperial \\
\hline & Loxura & L. atymnus & Yamfly \\
\hline & Zizina & Z. otis & Lesser grass blue \\
\hline \multirow[t]{16}{*}{ Nymphalidae } & Acraea & A. violae & Tawny coster \\
\hline & Amathusia & A. phidippus & Palmking \\
\hline & Danaus & D. melanippus & Black veined tiger \\
\hline & Discophora & D. sondaica & Common duffer \\
\hline & Elymnias & E. hypermnestra & Common palmfly \\
\hline & Euploea & E. eunice & Blue-banded king crow \\
\hline & Euthalia & E. aconthea & Common baron \\
\hline & & E. merta & White-tipped baron \\
\hline & Hypolimnas & H. bolina & Great eggfly \\
\hline & Junonia & J. atlites & Grey pansy \\
\hline & & J. iphita & Chocolate pansy \\
\hline & & J. hedonia & Brown pansy \\
\hline & & J. orithya & Blue pansy \\
\hline & Melanitis & M. leda & Common evening brown \\
\hline & Mycalesis & M. janardana & Common bush brown \\
\hline & & M. mineus & Dark-brand bush brown \\
\hline \multirow[t]{6}{*}{ Papilionidae } & Graphium & G. agamemnon & Tailed green jay \\
\hline & & G. evemon & Blue jay \\
\hline & Papilio & cf. P. iswara & Great Helen \\
\hline & & P. demoleus & Lime swallowtail \\
\hline & & P. demolion & Banded swallowtail \\
\hline & & P. memnon & Great Mormon \\
\hline
\end{tabular}




\begin{tabular}{llll} 
& P. polytes & Common Marmon \\
\hline Pieridae & Appias & A. libythea & Striped albatross \\
Catopsilia & C. pomona & Lemon emigrant \\
& C. pyranthe & Mottled emigrant \\
& C. scylla & Orange emigrant \\
Delias & D. hyparete & Painted Jezebel \\
Eurema & E. hecabe & Common grass yellow \\
& E. Sari & Chocolate grass yellow \\
& Leptosia & nina & Psyche \\
\hline
\end{tabular}

Jumlah spesies yang ditemukan ini jauh lebih banyak dari penelitian yang dilakukan Sugiarto pada tahun 2018 yang hanya menemukan 10 spesies. Beberapa spesies yang indentifikasi pada penelitian yang dilakukan Sugiarto (2018) dinilai salah seperti Papilio lowii yang secara morfologi lebih tepat diidenfikasi sebagai Papilio memnon, Carterocephalus palaemon lebih tepat diidentifikasi sebagai Ampittia dioscorides, Euchrysops cnejus lebih tepat diidentifikasi sebagai Zizina otis dan Abisara echerius lebih tepat diidentifikasi sebagai Junonia hedonia.

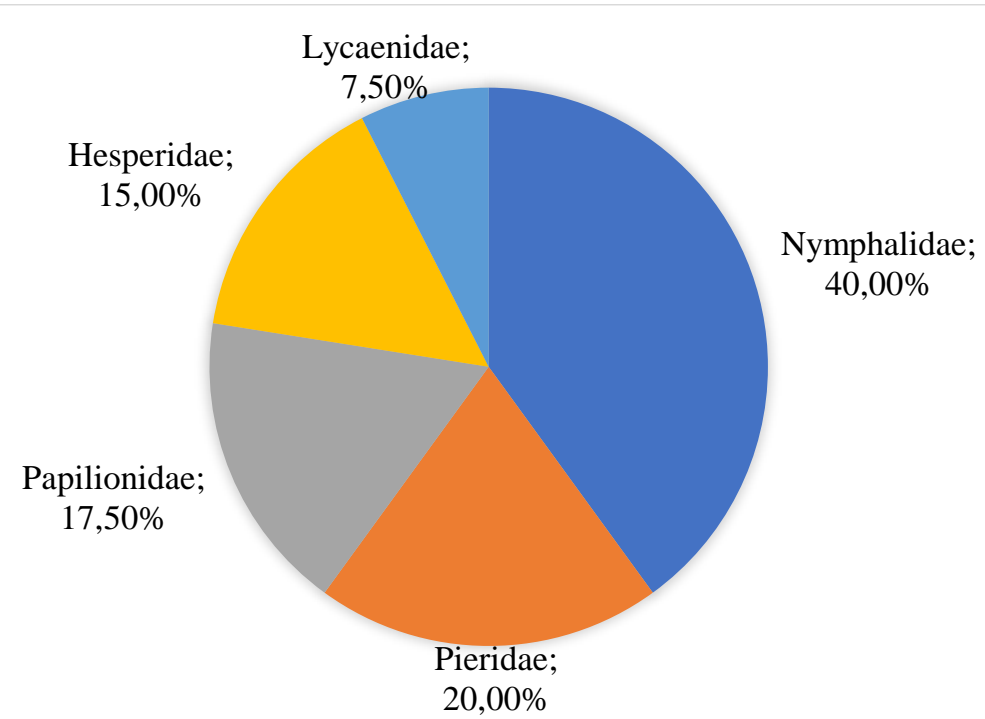

Gambar 1. Persentase kupu-kupu di Desa Serdang Menang

Persentase kupu-kupu (Gambar 1) menunjukkan spesies kupu-kupu dari famili Nymphalidae mendominasi dibanding spesies kupu-kupu dari famili lainnya. Beberapa hal yang menyebabkan spesies kupu-kupu dari lebih banyak dibanding famili lainnya yaitu: Kupu-kupu dari famili Nymphalidae memiliki sifat terbang kuat, aktif dan cepat (Dalem \& Joni, 2017) serta kupu-kupu dari Famili Nymphalidae cenderung bersifat polifag (mempunyai jenis makanan lebih dari satu macam), sifat inilah yang memungkinkan Nymphalidae tetap dapat memenuhi kebutuhannya akan tumbuhan inang meskipun tumbuhan inang utamanya tidak tersedia (Lestari et al., 2015).

Spesies kupu-kupu yang ditemukan di Desa Serdang Menang lebih banyak ditemukan di kawasan persawahan dan perkebunan, hasil ini menunjukkan hasil yang sama dengan penelitiaan yang dilakukan Sugiarto (2018) bahwa spesies kupu-kupu lebih banyak ditemukan pada perbatasan kawasan persawahan dan perkebunan. Hal ini diperkirakan karena tersedianya vegetasi untuk mendukung habitat dan makanan bagi kupu-kupu (Rahayu dan Basukriadi, 2012) (Septianella et al., 2015). 


\section{Kesimpulan}

Penelitian yang dilakukan menunjukkan ditemukan 40 spesie kupu-kupu dari 26 genus dan 4 famili, jumlah ini lebih banyak dibanding penelitian sebelumnya yang hanya ditemukan 10 spesies dari 10 genus dan 5 famili. Spesies kupu-kupu dari famili Nymphalidae mendominasi dibanding spesies kupu-kupu dari famili lainnya, sedangkan spesies kupu-kupu dari genus Papilio, Junonia dan Catopsilia merupakan spesies kupu-kupu yang lebih banyak ditemukan dibanding spesies kupu-kupu dari genus lainnya. Spesies kupu-kupu yang didapat banyak ditemukan pada kawasan persawahan dan perkebunan, ini dapat menjadi indikator bahwa pada kawasan persawahan dan perkebunan masih memiliki kualitas ekosistem yang baik.

\section{Daftar Pustaka}

Dalem, A.A.G \& M. Joni. 2017. Jenis-Jenis Kupu-Kupu Yang Ditemukan di Kawasan Pariwisata Ubud, Bali. Prosiding SEMINAR NASIONAL SAINSTEK 2017. 163-177.

Lestrasi, D.F., Rizma, D.A.P., Muhammad, R., dan Atika, D.P. 2015. Keanekaragaman kupu-kupu (Insekta: Lepidoptera) di Wana Wisata Alas Bromo, BKPH Lawu Utara, Karanganyar, Jawa Tengah. PROS SEM NAS MASY BIODIV INDO. 1(6): 1284-1288.

Rahayuningsih, M., R. Oqtafiana, dan B. Priyono. 2012. Keanekaragaman Jenis Kupu-Kupu Superfamili Papilionoidae di Dukuh Banyuwindu Desa Limbangan Kecamatan Limbangan Kabupaten Kendal. Jurnal MIPA. 35(1): 11-20.

Rahayu, S. E. \& A. Basukriadi. 2012. Kelimpahan dan Keanekaragaman Spesies Kupu-Kupu (Lepidoptera; Rhopalocera) Pada Berbagai Tipe Habitat di Hutan Kota Muhammad
Sabki Kota Jambi. Biospecies. 5(2): 40-48.

Septianella, G., Djunijanti, P., dan Hidayat, Y. S. 2015. Keanekaragaman kupukupu (Lepidoptera) di kawasan Desa Pasirlangu, Kecamatan Cisarua, Kabupaten Bandung Barat, Jawa Barat. PROS SEM NAS MASY BIODIV INDON. 1(8): 1816-1820.

Sugiarto, A. 2018. Inventarisasi KupuKupu di Desa Serdang Menang, Kecamatan Sirah Pulau Padang, Kabupaten Ogan Komering Ilir. Kumpulan Artikel Insect Village. 1(1): 1-3. 